Zabytkoznawstwo i Konserwatorstwo XLII, Toruń 2011

\title{
Obraz Madonna z Dzieciątkiem i Świętymi przypisywany naśladowcy Giulia Cesarego Procacciniego - próba datowania i określenia proweniencji dzieła na podstawie badań techniki malarskiej"
}

\section{Wprowadzenie}

$C_{1}$ braz Madonna z. Dqieciatkiem i Świetymi (il. 1) ze zbiorów Galerii Malarstwa Obcego Muzeum Narodowego w Poznaniu został wstępnie rozpoznany w latach 60. XX wieku. Czas jego powstania określono

* Artykuł został napisany na podstawie pracy magisterskiej zrealizowanej przez A. Lubochońską-Anusiak pod kier. dr hab. E. Basiul, prof. UMK, w Zakładzie Technologii i Technik Malarskich. Zob. A. Lubochońska-Anusiak, Obraz Madonna z. Drieciatkiem i Świetymi przypisywany naśladowcy Giulia Cesarego Procacciniego - próba datowania i określenia proweniencji dzieła na podstawie badań techniki malarskiej, ZTiTM UMK, Toruń 2000 [mps]. Autorki artykułu pragna podziękować Dyrekcji i Pracownikom Muzeum Narodowego w Poznaniu, szczególnie panu dr. Piotrowi Michałowskiemu - kustoszowi Działu Malarstwa Obcego, i pani mgr Agnieszce Lewandowskiej - głównemu konserwatorowi Muzeum, za życzliwość i wszelką pomoc okazaną podczas opracowywania tego tematu. 
wówczas na XVII wiek, a na podstawie analizy kompozycji, formy i typu przedstawionych na nim postaci jego autorstwo przypisano naśladowcy Giulia Cesarego Procacciniego działającemu w środowisku mediolańskim. Przywoływano przykłady dwóch prac tego artysty, które są najbliższe analizowanemu dziełu, tj. Madonna ₹ Drieciatkiem i głowami Aniołón (Mediolan, kolekcja Frizzoni) i Zaślubiny Świętej Katarayyny (Mediolan, Pinacoteca di Brera). Poziom wykonania obrazu oceniono jako niski w zestawieniu z innymi realizacjami Procacciniego ${ }^{1}$. Muzeum Narodowe w Poznaniu w swoich opracowaniach uznało dzieło Procacciniego z Galerii Malarstwa Dawnego w Dreźnie za wzór dla badanego przedstawienia (il. 2). Jednocześnie źródło to wzmiankuje również o znajdującej się w Luwrze kompozycji będącej dokładnym powtórzeniem analizowanego obrazu².

Giulio Cesare Procaccini był czołowym przedstawicielem szkoły lombardzkiej początku XVII wieku³. Urodził się w Bolonii w 1574 roku, zmarł w Mediolanie w roku 1625. Działał na terenie całych północnych Włoch, głównie w Mediolanie, ale również w Modenie, Parmie, Cremonie, Genui i Turynie ${ }^{4}$, realizując zlecenia na wielkie kompozycje ołtarzowe, freski, a także liczne obrazy olejne małej skali na prywatny użytek ${ }^{5}$. Jego twórczość często określa się mianem eklektycznej. Łączył on bowiem elementy manierystyczne z dramatyzmem i emocjonalnością baroku. Cechowała go niezwykła łatwość w przyswajaniu różnych trendów w sztuce, co spowodowało, że jego malarstwo jest bardzo niejednorodne stylowo ${ }^{6}$.

1 A. Dobrzycka, M. Skubiszewska, Malarstwo obce XVI-XVIII wieku Muzeum Narodowego w Poznaniu, Koszalin 1962, s. 34.

2 Informacje pochodzą z karty inwentaryzacyjnej obiektu znajdującej się w Muzeum Narodowym w Poznaniu.

3 Lombardia, będąca wówczas pod panowaniem Hiszpanii, przez pierwsze 30 lat XVII w. przeżywała rozkwit artystyczny. Szkoła lombardzka czerpała inspiracje z całych północnych Włoch, łącznie z Parmą, Wenecja, Genuą czy Florencją. Łączyła środki charakterystyczne dla manieryzmu z emocjonalnością protobaroku. Oprócz Procacciniego do czołowych przedstawicieli tej szkoły należeli: Cerano, Morazzone, Daniele Crespi. Zob. H. Brigstocke, Procaccini in America, London 2002, s. 11-13.

4 Ibidem, s. 29.

5 Ibidem, s. 63.

6 The dictionary of art, vol. 25: Pittoni to Raphael, ed. by J. Turner, New York 1998, s. 643 . 
Inspirował się wieloma malarzami: od Rafaela ${ }^{7}$, Correggia i Parmigianina, po Tintoretta, Tycjana ${ }^{9}$ oraz Rubensa ${ }^{10}$. Na podstawie literatury niewiele można powiedzieć o technice malowania Procacciniego czy też o stosowanych przez niego materiałach. Malował zarówno na podobraziach drewnianych, jak i płóciennych, głównie w technice olejnej, jednak zdarzają się też obrazy malowane temperą. Sposób malowania Procacciniego, podobnie jak styl, wykazuje dużą różnorodność.

Niewiele wiemy na temat dzieła Procacciniego znajdującego się obecnie w Muzeum Narodowym w Dreźnie ${ }^{11}$. Data jego powstania i miejsce pierwotnego przeznaczenia też nie sa znane. Duży rozmiar $162 \times 107,5 \mathrm{~cm}^{12}$, oraz podłużny format sugerują, że mógł on pełnić pierwotnie funkcję obrazu ołtarzowego. Wiadomo, że w kolekcji drezdeńskiej znajdował się już w latach 1722-1728 ${ }^{13}$. Dzieło będące pierwowzorem badanej kompozycji łączy elementy barakowe z manierystycznymi. Jest typowe dla twórczości Procacciniego ${ }^{14}$. Do manieryzmu nawiązuja przede wszystkim układ postaci pierwszoplanowych, ukazanych w skomplikowanym, nieco teatralnym, tanecznym ruchu, oraz przedstawienie Matki Boskiej, mającej lekko wydłużone proporcje i jednocześnie bardziej masywny korpus. Miękki sposób malowania karnacji, jak i wdzięk postaci

7 H. Brigstocke, op. cit., s. 56.

Ibidem, s. 11.

Ibidem, s. 41.

10 The dictionary, s. 643.

11 Die heilige Familie, Staatliche Kunstsammlungen Dresden, Gemäldegalerie Alte Meister, Gal. Nr. 643.

12 Gemäldegalerie Altemeister Dresden. Katalog der ausgestellten Werke, dir. A. Walther, Dresden 1983, s. 178. Obraz nie był badany pod względem budowy techniczno-technologicznej. Wymieniony tu katalog podaje, że został on namalowany olejem na desce $z$ drewna dębowego.

13 Dokładna historia obrazu nie jest znana, nie wiadomo, jakie było jego pierwotne przeznaczenie i kiedy dokładnie stał się częścią kolekcji Muzeum Narodowego w Poznaniu. W katalogu muzeum poświęconym malarstwu dawnemu znajduje się wzmianka, że obraz był inwentaryzowany w latach 1722-1728 oraz że został nabyty przez Perodiego w 1728 r. jako Caravaggio. Zob. Gemäldegalerie Altemeister Dresden, s. 178.

14 H. Brigstocke, op. cit., s. 11. 
Jezusa i Madonny to zauważalne wpływy Correggia i jego naśladowców ${ }^{15}$. Element barokowy stanowi zaś maniera pittura tenebrosa. Jej wyrazem jest operowanie silnymi kontrastami światła i cienia oraz przewaga mroku w przedstawieniu ${ }^{16}$. Charakterystyczna dla szkoły mediolańskiej jest kompozycja obrazu, podzielona na plany przez stopniowanie światła, oraz ciemna kolorystyka. Temat obrazu - Święta Rodzina - był bardzo popularny w drugiej połowie XVI i w XVII wieku ${ }^{17}$.

Zasadniczą różnicę między badanym dziełem a pierwowzorem stanowi ich rozmiar. Kopia jest szesnastokrotnie pomniejszona w stosunku do oryginału. Inny jest również rodzaj zastosowanego podłoża. Pierwowzór został namalowany na desce dębowej, analizowane dzieło zaś na podobraziu płóciennym. Oba przedstawienia łączy opracowanie malarskie w technice olejnej. Jednocześnie obraz z Muzeum Narodowego w Poznaniu wiernie odtwarza kompozycję i styl pierwowzoru. Kolorystyka, układ postaci oraz poszczególne formy są niemal identyczne z oryginałem. Naśladowca starał się dokładnie oddać nastrój dzieła, sposób potraktowania światła oraz aparycje postaci. Różnice występują w sposobie opracowania malarskiego, w detalach kompozycji oraz charakterze rysunku, który jest mniej sprawny i bardziej schematyczny. Brakuje w nim zręczności i pewności ręki widocznej w oryginale. Można zaobserwować uproszczenia w przedstawieniu rysów twarzy, rąk, włosów. W opracowywaniu karnacji, zwłaszcza postaci pierwszoplanowych, artysta usiłował uzyskać efekt zbliżony do pierwo-

15 M. Rzepińska, Malarstwo cinquecenta, Warszawa 1989, s. 180-190.

16 Maniera ta jest powszechna w malarstwie północnowłoskim drugiej połowy XVI w., jak i w malarstwie barokowym (zwłaszcza kręgu Caravaggia). W obrazie jest widoczna, rozwijająca się w XVII w., tendencja do coraz mocniejszego pogłębiania mroku, który w tle dochodzi niemal do zupełnej czerni, co powoduje, że lokalizacja sceny jest nieczytelna. Zob.: M. Rzepińska, Zjawisko tenebryzmu w malarstwie XVII w. i jego podto ze ideowe, [w:] eadem, W kregu malarstwa, Wrocław 1988, s. 115-121; Stownik terminologiczny sztuk pieknych, pod red. K. Kubalskiej-Sulkiewicz, M. Bielskiej-Lach, A. Manteuffel-Szaroty, Warszawa 2002.

17 Matka Boska, której kult zwalczali protestanci, oraz życie Świętej Rodziny były tematami bardzo często pojawiającymi się w sztuce XVII w., z tym że sceny te ukazywano w sposób świecki. Zob. Galeria malarstwa obcego: malarstwo włoskie, hiszpańskie, francuskie XV, XVI, XVII, XVIII wieku, Muzeum Narodowe w Warszawie, Warszawa 1955, s. 83. 
wzoru. Modelunek karnacji jest miękki, z łagodnymi przejściami od światła do cienia i zmiękczonym konturem. W powtórzeniu zabrakło jednak plastyczności modelunku, widocznej na obrazie Procacciniego, a postacie wydają się bardziej płaskie. Idealnie gładki modelunek ciała, bez śladów pociagnięć pędzla, widoczny w pierwowzorze, kontrastuje ze sposobem potraktowania tkanin, malowanych impastowo, szybkimi, pewnymi pociągnięciami pędzla. W obrazie z Muzeum Narodowego w Poznaniu przedstawienie to jest malowane raczej gładko, jedynie w partiach najwyższych szat - bardziej impastowo. Najwyższe światła rękawów czerwonej i spodniej szaty Marii są oddane przez drobne impastowe pociagnięcia pędzla, które wydają się naśladować sposób modelowania tych partii w oryginale. Czerwony płaszcz Marii w pierwowzorze sprawia wrażenie, jakby był z metalu. Taka rzeźbiarska technika modelowania fałd tkanin jest charakterystyczna dla Procacciniego i występuje w wielu jego kompozycjach ${ }^{18}$. W badanym obrazie nie ma tego efektu. Fałdy naśladuja ogólne formy widoczne w oryginale, ale sa płaskie, potraktowane dość schematycznie. Na podstawie powyższej analizy, wykazującej dużą zgodność nie tylko w kompozycji i formie, ale także w kolorystyce oraz w sposobie modelowania niektórych partii, z dużym prawdopodobieństwem można stwierdzić, że badane dzieło zostało namalowane bezpośrednio z oryginału.

\section{Badanie techniki i technologii obrazu*}

\section{Badania nieniszczące ${ }^{* *}$}

Analiza wizualna powierzchni warstwy malarskiej wykazuje, że paleta barwna w badanym obrazie jest zawężona. Składaja się na nią żółcień, dwa odcienie czerwieni, błękit, brązy, czerń i biel. Oryginalna kolorysty-

18 H. Brigstocke, op. cit., s. 21.

* Szczegółowa dokumentacja badań znajduje się w Zakładzie Technologii i Technik Malarskich IZK UMK.

** Fotografie w świetle widzialnym, fluorescencji w świetle UV, reflektografii UV, reflektografii IR, barwnej podczerwieni wykonał mgr A. Cupa w Zakładzie Technologii i Technik Malarskich UMK w Toruniu. Zdjęcia rentgenowskie wykonano w Akademickiej Przychodni Lekarskiej w Toruniu. 
ka jest silnie zakłócona przez pożółkły werniks, który nadaje cieplejszy i ciemniejszy ton całej kompozycji. Na podstawie obserwacji powierzchni obrazu za pomoca lupy i wideomikroskopu ustalono typ spękań występujących w warstwie malarskiej. Są one nieliczne i zauważalne tylko w określonych partiach. Sa to przede wszystkim spękania pierwotne, przechodzące wyłącznie przez warstwę malarską i niesięgające zaprawy ${ }^{19}$. Występują one głównie w partiach cieni, gdzie okiem nieuzbrojonym można dostrzec arabeskę spękań w postaci rozejść, ukazujących białą zaprawę. Spękania te w wielu miejscach łączą się ze sobą, tworząc siatkę. Szczególne zagęszczenie arabeski spękań jest widoczne na twarzach postaci drugoplanowych, wtopionych ciemnym, brązowym laserunkiem w tło. W tych miejscach arabeska spękań jest bardziej nieregularna, przypomina spękania ostowate lub zatokowe (il. 3$)^{20}$. Najważniejsza przyczyna powstania tego typu spękań wczesnych jest najprawdopodobniej błąd techniczny, czyli nałożenie farby na niedostatecznie wyschniętą warstwę spodniąa ${ }^{21}$. Dodatkowo mogło przyczynić się do tego zastosowanie laserunku z pigmentu wolno schnącego w oleju ${ }^{22}$. W partiach najwyższych świateł karnacji Chrystusa, w miejscach, gdzie były one malowane gęstą, białą farbą, zauważono pojedyncze spękania, przebiegające zazwyczaj zgodnie z ruchem pędzla. Ten typ spękań pierwotnych powstaje na ogół w obrazach

19 Charakterystykę spękań pierwotnych (wczesnych) podaje Slánský. Zob. B. Slánský, Technika malarstwa, t. 2, Toruń 1965, s. 137.

20 Ibidem, s. 122-141.

21 Jeśli dolna warstwa olejna, która nie wyschła dostatecznie, zostaje pokryta drugą warstwą farby o innym składzie, to podczas ich schnięcia tworzą się naprężenia nie tylko wewnątrz poszczególnych warstw, ale także między nimi, w wyniku czego obie peckają. Ibidem, s. 139.

22 Spękania pierwotne w postaci rozejść powstają często również w wyniku stosowania pigmentów organicznych pochodzenia roślinnego i zwierzęcego, barwników smołowcowych i bitumicznych - pigmentów długo schnących bądź nieschnących w oleju, szczególnie gdy są one stosowane w grubszych, spodnich warstwach. Najszersze i najbardziej regularne spękania powstają w farbach zawierajacych asfalt. Ten typ spękań jest też charakterystyczny dla czerni kostnej, lampowej, brunatu kasselskiego, brunatu van Dycka. Siatka spękań jest łagodniejsza, jeśli farba wymagająca dużej ilości oleju była stosowana, jak w tym przypadku, w wierzchniej warstwie, nakładanej cienko, równomiernie. Zob. ibidem, s. 138-139. 
olejnych malowanych na olejnej zaprawie w technice alla prima ${ }^{23}$. Przeważają spękania w kierunku pionowym, są one rzadko usiane, większość nie łączy się ze soba. Na powierzchni obrazu w okolicy kolana Dzieciątka występują charakterystyczne spękania ślimakowate, powstałe wtórnie w wyniku uderzenia ${ }^{24}$. Oględziny krajek i odwrocia pozwoliły na określenie barwy zaprawy. Jest ona widoczna na odwrociu, w miejscach, gdzie przeszła na drugą stronę, oraz na krajkach - pokrywa całą ich powierzchnię i ma kolor biały. Podobrazie tworzy płótno o splocie prostym (płóciennym), tkane równomiernie, ale użyte nitki maja różna grubość. Przez środek płótna, w kierunku pionowym, przebiega charakterystyczne zafalowanie nitek. Stan zachowania płótna określono jako ogólnie dobry. Na odwrocie nosi ono ślady ingerencji konserwatorskiej w postaci naklejonej łaty. Krajki płótna, pokryte w całości zaprawą, aż do krawędzi, są bardzo dobrze zachowane. Ich krawędzie są ostro zakończone, a nitki niepostrzępione. Brakuje jakichkolwiek uszkodzeń w postaci dziur lub ugięć nitek mogących świadczyć o wcześniejszym mocowaniu na krosnach pomocniczych czy też przeniesieniu na nowe krosna. Nie zaobserwowano występowania bitego brzegu, w związku z tym określenie przebiegu wątku i osnowy było utrudnione. Za wątek uznano nitki biegnące pionowo, ze względu na mniejszą gęstość liniową, słabszy skręt i mocniejsze wrobienie w porównaniu $z$ nitkami przebiegającymi poziomo ${ }^{25}$. Oznaczenie gęstości liniowej płótna nitek biegnących pionowo (uznanych za wątek) wynosi $12-13 \mathrm{~cm}$, a nitek biegnących poziomo (uznanych za osnowę) - 15-16 cm. Ciężko jednoznacznie stwierdzić, czy krosna, na których jest napięty obraz, sa wtórne. Jak już wyżej wspomniano, nie ma żadnych śladów uszkodzeń

23 Slánský podaje, że w jednolitej warstwie olejnej siły naprężeń powstające w wysychającej farbie działają poprzecznie do kierunku pociagnięć pędzla. Warstwa malarska pęka w miejscach, w których farby jest najmniej, tj. w bruzdach, będących śladami pędzla. Zob. ibidem, s. 141.

24 Ibidem, s. 130.

25 Najpewniejszy sposób określenia kierunku wątku i osnowy to odnalezienie bitego brzegu, który jest zawsze równoległy do osnowy. Kierunek wątku i osnowy można również ustalić na podstawie takich cech, jak gęstość liniowa, siła skrętu i wrobienia nitek. Siłę skrętu i wrobienie określono wizualnie, porównując fragmenty nitek pobranych z obiektu. Korzystano z informacji zawartych w pracy: B. J. Rouba, Ptótna jako podobraz̨ia malarskie, „Ochrona Zabytków”, 1985, nr 3-4, s. 225. 
płótna w miejscu krajek, mogących świadczyć o ich wymianie ${ }^{26}$. Są to fazowane krosna o połączeniach ruchomych, widlicowych z dwoma klina$\mathrm{mi}^{27}$. Zewnętrzne krawędzie krosien od strony odwrocia są lekko ścięte. $\mathrm{Na}$ listwach krosien znajdują się liczne nalepki inwentaryzacyjne mówiące o historii obrazu: nalepka z numerem KFMP 829 z rejestrów niemieckich Kaiser-Friedrich Museum, nalepka z napisem Procaccini, wykonanym cyrylica, nalepka z numerem inwentaryzacyjnym Muzeum Narodowego w Poznaniu: MO 830 (il. 4).

Rejestracja fluorescencji obrazu w świetle ultrafioletowym pozwala przede wszystkim na zaobserwowanie koloru i intensywności świecenia poszczególnych pigmentów oraz spoiwa, a także na identyfikację warstw wtórnych ${ }^{28}$. W przypadku badanego obiektu na całej powierzchni lica jest widoczna silna fluorescencja grubo położonego wtórnego werniksu. Wyraźnie uczytelnił się dukt pędzla, którym był on rozprowadzany. Werniks utrudnia analize fluorescencji warstwy malarskiej. Bardzo dobrze uwydatniły się natomiast miejsca przemalowań i retuszy. Uzupełnienia warstwy malarskiej, wykonane na werniksie, uwidoczniły się w postaci czarnych plam. Na zdjęciu można również dostrzec miejsca przemalowań znajdujących się pod werniksem. Są one nieco ciemniejsze w tonacji od pozostałych partii kompozycji. Przebiegają częściowo po formie, pogłębiając cienie. Przez silną fluorescencję werniksu można zauważyć intensywne świecenie warstw malowanych $\mathrm{z}$ dużym udziałem bieli ${ }^{29}$ oraz delikatne, chłodnoróżowe świecenie niektórych partii karnacji i szat, sugerujące uży-

26 Nie można wykluczyć, że w procesie konserwacji krosna zostały wymienione, a gwoździe wbite dokładnie w te same miejsca, w których znajdowały się pierwotne gwoździe, tak by nie uszkodzić płótna.

27 Określając typ krosien, wzięto pod uwage terminologię zawartą w pracy: A. Diakowska-Czarnota, Typologia drewnianych krosien malarskich na podstawie kryterium złaçyy, „Ochrona Zabytków”, 1984, nr 1.

28 Zob.: J. Rogóż, A. Cupa, M. Poksińska, Badania nieniszrzace dzieł sz̨tuki z̧a pomoca systemu do reflektografii cyfrowej NIR 2000 i systemu do badan termowizyjnych REYTHEON CONTROL IR 2000B, [w:] Ars longa - vita brevis. Tradycyjne i nowoczesne metody badania dziet sztuki. Materialy z sesji naukowej poświeconej pamięci profesora Zbigniewa Brochwicza, Toruń 18-19 X 2002, pod red. J. Flika, Toruń 2003, s. 99.

29 Warstwy malowane z użyciem bieli (np. ołowianej, cynkowej) mają silną fluorescencję. B. Slánský, op. cit., s. 45. 
cie czerwieni organicznej. Fotografia w świetle UV ułatwiła wytypowanie miejsc pobrania próbek. W badanym przypadku zdjęcie reflektografii w UV nie wykazało istotnych zmian i poprawek w warstwie malarskiej i werniksie.

Analiza fotografii w bliskiej podczerwieni (reflektografia IR) pozwoliła na wniknięcie w strukturę obrazu, dzięki czemu możliwe jest poznanie jego techniki, głównie rysunku. Na czytelność rysunku w promieniowaniu IR decydujący wpływ ma materiał, jakim został on wykonany, oraz rodzaj zaprawy $^{30}$. Na fotografii w bliskiej podczerwieni badanego obrazu rysunek był widoczny bardzo wyránie (il. 5), na co może wpływać fakt, że warstwy malarskie są cienkie, a rysunek jest wykonany na białej zaprawie, prawdopodobnie z użyciem czarnego pigmentu (czerń żelazowa, roślinna, węglowa) ${ }^{31}$. Zaobserwowano występowanie linearnego, konturowego rysunku. Nie dostrzeżono zaś opracowania światłocieniowego. Niektóre partie nie pokrywają się z opracowaniem malarskim. Na zdjęciu uwidoczniły się również uzupełnienia warstwy malarskiej (w okolicy szyi Świętego stojącego bliżej Marii).

Porównanie zdjęcia obrazu w świetle VIS ze zdjęciem w technice fałszywych kolorów pozwoliło na wstępną identyfikację niektórych pigmentów wykorzystanych do namalowania poszczególnych partii obrazu (il. 6) ${ }^{32}$. Pigmenty użyte do namalowania najwyższych świateł nie stwarzały problemów w interpretacji wyników badań, natomiast półtony i naj-

$30 \quad$ J. Flik, J. Olszewska-Świetlik, A. Cupa, A. Wypych, Rysunek w malarstwie sz̨talugowym - badania metoda reflektografii w podczerwieni, [w:] Ksiega pamiatkowa ofiarowana profesorowi Wiestawowi Domasłowskiemu, pod red. B. Soldenhoff, Toruń 2002.

31 W zestawieniu z innymi materiałami rysunki wykonane czernią roślinną, a także innymi czarnymi pigmentami, niezależnie od tego, w jakim spoiwie się je stosuje, sa najczytelniejsze w promieniowaniu IR. Wynika to z faktu, że czernie sa najmniej przenikliwe dla promieniowania IR. Ibidem, s. 56. Natomiast rysunek wykonany atramentem, tuszem jest praktycznie niewidoczny w promieniowaniu IR. Zob. B. Slánský, op. cit., s. 60

32 Interpretacji zdjęć w kolorowej podczerwieni dokonano, opierając się na konsultacjach z dr. J. Rogóżem oraz na informacjach zawartych w publikacjach: J. Rogóż, Fotografia kolorowa w bliskiej podczerwieni „technika fatşywych kolorów”, [w:] Od badań do konserwacji: materialy z. konferencji 23-24 października 1998, Torun 2002; T. Moon, R. Schelling, S. Tirkette, $A$ note on the use of false-color infrared photography in conservation, „Studies in Conservation”, 1992, no. 37, s. 42-52. 
głębsze cienie malowane mieszaniną kilku pigmentów oraz pogłębiane laserunkiem były trudne do jednoznacznego rozpoznania. Jeżeli pigmenty występują w mieszaninie lub są nakładane warstwowo, kolor otrzymany na zdjęciu będzie wypadkową efektów chromatycznych każdego z nich ${ }^{33}$. Partie białe w świetle VIS, jak i malowane $z$ przewagą bieli (tj. karnacje Madonny i Dzieciątka, partie najwyższych świateł) mają w kolorowej podczerwieni barwę biała. Świadczy to o bardzo dużym udziale bieli ołowianej w tych miejscach ${ }^{34}$. Detale twarzy, widoczne w świetle VIS jako różowe, a w barwnej podczerwieni jako pomarańczowe, wskazuja na użycie czerwieni organicznej (usta, kontur oczu Chrystusa). Niektóre partie, różowe w świetle VIS (m.in. policzki, usta, nos Madonny, Dzieciątka i innych postaci, rękaw czerwonej tuniki Madonny), w kolorowej podczerwieni sa jasnożółte. Kolor żółty jest charakterystyczny dla minii i cynobru ${ }^{35}$. Karnacja Świętego z księga oraz zacienione partie karnacji pozostałych postaci maja w technice fałszywych kolorów zbliżony odcień zielonobrązowej szarości. Może to świadczyć o tym, że zostały opracowane z dużym udziałem pigmentów żelazowych - żółtych, czerwonych, brązowych, rozjaśnianych w światłach bielą ${ }^{36}$, oraz że zostały przyciemnione i scalone tym samym końcowym laserunkiem. Czerwone szaty Marii i Świętego stojącego obok niej w półtonach są widoczne w kolorowej podczerwieni jako brudnozielone, co sugeruje użycie czerwieni żelazowych. Natomiast w partiach cieni zmieniają kolor na pomarańczowobrunatny. Zbliżony odcień mają również włosy Madonny i Świętego obok niej (w świetle VIS ich odcień jest nieco cieplejszy niż cienie czerwonych szat), co może sugerować, że partie te sa pokryte tym samym końcowym laserunkiem przyciemniającym.

33 J. Rogóż, op. cit., s. 231.

34 Kolor biały w technice fałszywych kolorów występuje również w przypadku żółcieni neapolitańskiej, została ona jednak wyeliminowana w dalszych badaniach na pobranych próbkach. Zob. T. Moon, R. Schelling, S. Tirkette, op. cit., s. 49.

35 Minia i cynober wykazują w technice fałszywych kolorów barwę jasnożółtą. Zob. J. Rogóż, op. cit., s. 231.

36 Umbra ma w technice fałszywych kolorów kolor brązowy lub czarny, czerwień żelazowa brunatnozielony, żółcienie żelazowe kolor zbrudzonych bieli. Zob. T. Moon, R. Schelling, S. Tirkette, op. cit., s. 49. Interpretacji dokonano, opierając się na konsultacjach z dr. J. Rogóżem. 
Kompozycja obrazu na rentgenogramie jest prawie nieczytelna (il. 7). Obraz przytłumia biała zaprawa. Na tej podstawie można wnioskować, że w jej skład wchodzi biel ołowiana, która silnie pochłania promienie Roentgena ${ }^{37}$. W postaci rozmytych, jasnych plam widoczne sa jedynie najsilniej oświetlone partie kompozycji, malowane ze znacznym udziałem bieli (karnacje Dzieciątka i Madonny, światła na rękawie płaszcza Marii i wychodzącego spod niego rękawa białej tuniki oraz biała draperia zasłaniająca plecy Chrystusa). Stąd można wnosić, że partie białe sa namalowane $z$ użyciem dużej ilości bieli ołowianej ${ }^{38}$. Poza tym farba jest w tych miejscach położona w grubszej warstwie niż w pozostałych, co dodatkowo podwyższyło absorpcje promieni RTG. Reszta, namalowana farbami nieabsorbującymi lub słabo absorbującymi promieniowanie, pozostaje niewidoczna. Na zdjęciu są też zauważalne ciemne plamy zlokalizowane w obrębie uzupełnień oryginalnej warstwy malarskiej, dostrzegalnych na zdjęciu fluorescencji w UV. Na rentgenogramie bardzo wyraźnie uwydatniła się struktura płótna w postaci reliefu odciśniętego w zaprawie. Widać również, iż zafalowania nitek płótna w pobliżu krajek pokrywaja się z miejscami wbitych w krosna gwoździ. Zdjęcie w promieniach RTG wyjaśnia także przyczynę charakterystycznych ugięć pionowo przebiegających nitek osnowy. Są one wynikiem niepoprawnego napięcia płótna na krosnach. Płótno zostało przybite gwoździami najpierw z jednej strony, wzdłuż całej krawędzi, a dopiero potem naciagnięte $z$ drugiej strony, co spowodowało deformacje.

\section{Badanie próbek warstwy malarskiej}

Ze względu na bardzo dobrze zachowaną, gładką warstwę malarską liczbę próbek ograniczono do minimum. Miejsca pobrania próbek wytypowano, uwzględniając fotografię fluorescencji w świetle UV, aby wykluczyć obszary ingerencji konserwatorskich. Pobrano materiał badawczy następujących miejsc na obrazie: 1 - karnacja, noga Chrystusa, półton; 2 - błękit z płaszcza Marii, partia świateł; 3 - czerwień z szaty Świętego, partia

37 M. Roznerska, M. Kiepuszewska, Promieniowanie Roentgena w badaniu dzieł sqtuki-istota, źródła, metody, zastosowanie, Toruń 1991, s. 78-79.

38 Ibidem, s. 55. 
świateł; 4 - czerń z partii tła, górny prawy róg - sama warstwa malarska; 5 - czerń z partii tła, lewy dolny róg; 6 - zaprawa z krajki; 7 - zaprawa z odwrocia obrazu.

Część próbek poddano badaniom spektrograficznym XRF w celu wykrycia pierwiastków wchodzących w skład warstw malarskich i zapra$w^{39}$. Pigmenty oraz spoiwa warstwy malarskiej i zaprawy identyfikowano również za pomocą reakcji mikrochemicznych, przeprowadzonych bezpośrednio na próbkach, jak i na ich przekrojach. Podobnie rodzaj płótna i przeklejenia określono na podstawie badań mikrochemicznych wykonanych na pobranym z podobrazia materiale. W tym zakresie przeprowadzono analizę termiczna, obserwowano cząstki pod mikroskopem w powiększeniu 100×, w świetle przechodzącym i odbitym, w rozmazie wodnym, przeprowadzono reakcje $z$ kwasami i zasadami, reakcje z $2 \mathrm{n} \mathrm{Na}_{2} \mathrm{~S}$, zmydlanie, reakcje mikrochemiczne identyfikujące poszczególne pigmenty. Jedynie identyfikacji pigmentu czarnego dokonano, porównując czastki pigmentu czarnego z wzorcami ${ }^{40}$.

Z części materiału wykonano przekroje stratygraficzne. Ich analiza za pomocą metody mikroskopii fluorescencyjnej pozwoliła na poznanie budowy stratygraficznej warstwy malarskiej oraz na wskazanie cech charakterystycznych składających się na nią warstw. Określono ich kolor i grubość, ich wzajemną relację i sposób nakładania. Udało się też częściowo ustalić barwę ziaren niektórych pigmentów wchodzących w skład poszczególnych warstw. Analiza zdjęć przekrojów w UV umożliwiła wstępną identyfikację niektórych pigmentów i spoiwa oraz uwidoczniła występowanie warstw technologicznych niedostrzegalnych w świetle VIS ${ }^{41}$.

39 Badania XRF wykonał mgr A. Cupa na spektrometrze rentgenowskim MiniPal 4.

40 Analizę mikrochemiczną przeprowadzono na podstawie następujących pozycji: E. Mirowska, B. Rouba, M. Poksińska, I. Wiśniewska, Identyfikacja podobrazi i spoin malarskich w zabytkonych dziełach sztuki, Torun 1992; P. Rudniewski, Pigmenty i ich identyfikacja, Warszawa 1995.

41 Analizę fotografii w świetle UV przeprowadzono na podstawie pracy: Z. Rozłucka, M. Roznerska, J. Arszyńska, Mikeroskopia fluorescencyjna. Zastosowanie w badaniu budowy i procesów konserwacji malarstwa sz̨talugowego, Torun 2000, oraz konsultacji z p. Z. Rozłucka. 
Przeprowadzone badania pozwoliły na ustalenie rodzaju materiałów wykorzystanych do namalowania obrazu. Określono rodzaj podłoża malarskiego, składniki zaprawy i warstwy malarskiej. W podłożu obrazu zidentyfikowano płótno lniane o splocie płóciennym. Płótno było tkane ręcznie ${ }^{42}$. Uznano, że nitki biegna w obrazie poziomo, nitki wątku - pionowo. Gęstość liniowa nitek uznanych za wątek wynosi 12-13 cm; nitek uznanych za osnowę: 15-16 cm. Użyta przędza jest „Z” skrętna ${ }^{43}$, nierównomierna. Nitki mają różną grubość. W zaprawie zidentyfikowano biel ołowianą, kredę oraz spoiwo olejne.

Biel ołowianą chętnie stosowano jako wypełniacz zapraw, zarówno w XVII, jak i XVIII wieku, m.in. ze względu na dobre właściwości sykatywujące, z tym że na ogół występowała ona w mieszaninie z innymi pigmentami. Do gruntów często wykorzystywano ją, tak jak w tym przypadku, w mieszaninie z kredą ${ }^{44}$. Mieszanina bieli ołowianej z kreda jest określana $\mathrm{w}$ traktatach i podręcznikach malarskich jako ceruse $^{45}$. Mieszanina bieli ołowianej z kredą w stosunku 1:1 jest określana jako biel hiszpańska ${ }^{46}$. W tym przypadku kreda stanowi jednak tylko domieszkę. Przeprowadzone badania laboratoryjne pozwoliły stwierdzić, że paleta, która zastosował artysta, jest bardzo skromna, tworza ją bowiem pigmenty żelazowe pochodzenia ziemnego - czerwień i żółcień żelazowa, umbra, ewentualnie sjena palo-

42 W przypadku płócien tkanych ręcznie obowiązywała zasada, by stosunek wątku do osnowy był w przybliżeniu stały. $\mathrm{Na} 2 / 3$ osnowy przypadała $1 / 3$ wątku. W przypadku badanego płótna proporcja watku do osnowy jest zbliżona do zasad obowiązujących w tkactwie ręcznym. B. J. Rouba, Płótna jako podobrazia, s. 222-224. Świadczy o tym również nierównomierność grubości nitek.

43 Kierunek skrętu „Z” występuje zawsze w płótnach, w których przędza została przygotowana ręcznie. Ibidem, s. 224.

44 J. Czernichowska, Technika i technologia XVII-wiecznych obrazów praypisywanych Tomaszowi Dololabelli. Św. Stanistaw prowadzacy Piotrowina przed sad królewski i Gniew Boży w kościele oo. Bernardynów w Warcie w świetle badań i materiatów źródtowych, [w:] Ars longa - vita brevis, s. 198. Autorka podaje informację za: A. R. Duval, Les préparations colorées de tableaux de l'École française des dix-septième et dix-huitième siècles, „Studies in Conservation”, 1992, no. 37, s. 239-258.

45 Tak określa ją m.in. Watin w swoim traktacie. J. F. Watin, L'art du Paintre, Doreur, Vernisseur (Paris 1751). Zob. J. Szpor, Michałowski nieznany: materiały malarskie i technika w obrazach olejnych Piotra Michałowskiego, Warszawa 1991, s. 56.

46 J. Hopliński, Farby i spoiwa malarskie, Wrocław 1990, s. 136. 
na. Jedyny biały pigment zidentyfikowany w warstwie malarskiej to biel ołowiana. Jest to najczęściej stosowany w malarstwie biały pigment - od starożytności do połowy XIX wieku ${ }^{47}$. Do zidentyfikowanych czerwonych pigmentów należy czerwień organiczna - kraplak (czerwień krapowa) ${ }^{48}$. Należał on do powszechnie wykorzystywanych w XVII, XVIII i na początku XIX wieku czerwieni organicznych. Został użyty do laserunków pogłębiających tony czerwone oraz w karnacji do nadania im chłodnego różowego odcienia. Nie można również wykluczyć zastosowania cynobru lub minii do namalowania niektórych partii czerwonych (fragmenty karnacji). Podstawę palety stanowią brązy i czerwienie żelazowe. Czerwień żelazowa została zidentyfikowana przede wszystkim w partiach czerwonych szat, jak też w niewielkich ilościach w karnacji Chrystusa. Jest to czerwień pochodzenia naturalnego. Występowanie czerwieni lub brązów żelazowych stwierdzono także w karnacji postaci drugoplanowych. Oprócz tych pigmentów żelazowych w trakcie badań wykryto obecność umbry i sjeny palonej (czerwona szata, ciemne tło, partie ziemi), które są pigmentami pochodzenia ziemnego, znanymi od czasów starożytnych. Sjena i umbra palona powstają w wyniku prażenia odpowiednio sjeny lub umbry naturalnej ${ }^{49}$. W partiach karnacji Chrystusa zidentyfikowano żółcień żelazowa (ugier), a w błękitnym płaszczu oraz w ciemnym tle - błękit pruski, zwany też błękitem berlińskim ${ }^{50}$. Stwierdzono również obecność czerni roślinnej. Występuje ona w mieszaninie z innymi pigmentami, przede wszystkim w partii ciemnego tła. W karnacji pojawia się jako domieszka modyfikująca nieznacznie odcień w miejscach półtonów. W wielu przypadkach wykryto występowanie pierwiastka miedziowego, co może wynikać z dodatku mie-

47 Od połowy XIX w. wypiera ją biel cynkowa. B. Slánský, op. cit., s. 24-25.

48 Na podstawie barwy fluorescencji można wstępnie określić rodzaj czerwonego laku. Kraplak wykazuje fluorescencję ciepłą w odcieniu - oranżową, kermes - różowa, karmin - fioletową. Intensywność fluorescencji jest różna w zależności od substratu, na jakim został osadzony lak. W przypadku kraplaku także ilość purpuryny, jednego z głównych jego składników, obok alizaryny, ma wpływ na fluorescencję. Za: J. Olszewska-Świetlik, Z. Rozłucka, Badania czerwonych laserunków metoda mikroskopii fluorescencyjnej UV, „Acta Universitatis Nicolai Copernici. Zabytkoznawstwo i Konserwatorstwo", 2005, t. 34, s. 141-160.

49 J. Hopliński, op. cit., s. 152, 172.

50 B. Slánský, op. cit., s. 49. 
dzianki jako sykatywy do oleju w celu przyspieszenia schnięcia obrazu ${ }^{51}$. Spoiwem zastosowanym zarówno w zaprawie, jak i w warstwie malarskiej jest olej ${ }^{52}$. W XVIII i w pierwszej połowie XIX wieku jako spoiwa do farb chętnie używano, obok oleju lnianego, także oleju makowego, ze względu na jego bezbarwność, oraz oleju orzechowego. Dodawanie oleju makowego lub orzechowego zalecano zwłaszcza do bieli ołowianej $j^{53}$.

\section{Technika wykonania obrazu - interpretacja przeprowadzonych badań}

Jako podobrazie do namalowania analizowanej kompozycji zastosowano płótno lniane, ręcznie tkane, o wymiarach $44 \times 30,7 \mathrm{~cm}$. Jest ono tkane raczej gęsto i równomiernie, ma drobny gren - jego faktura prawie nie uwidacznia się na licu, mimo stosunkowo cienkiej warstwy zaprawy. Zaprawa pokrywa je na całej powierzchni, łącznie z krajkami. Brakuje jakichkolwiek śladów po ewentualnym mocowaniu na krosnach pomocniczych $^{54}$. To wszystko może świadczyć o tym, że płótno zostało wycięte z większego kawałka, wcześniej przeklejonego i zagruntowanego na kro-

51 Zastosowanie miedzianki (zieleni hiszpańskiej) jako sykatywy do oleju jest zalecane m.in. w traktacie Palomina (1715). Zob. J. Hopliński, op. cit., s. 124.

52 Ze względu na ograniczoną możliwość pobierania próbek nie wykonano szczegółowych badań rodzaju zastosowanego oleju.

53 W. Ślesiński, Na çym i caym malowano w dobie romantyzmu w Krakowie, „Ochrona Zabytków", 1969, nr 2, s. 121. Oleje makowy i orzechowy są wymienione m.in. w pracy z 1764 r. - N. N. The Handmaid to the Arts, cytowanej przez Bergera. E. Berger, Quellen für Maltechnik während der Renaissance und deren Folgezeit, München 1901, s. 423. Olej makowy do pigmentów białych zaleca m.in. Bardwell (połowa XVIII w.), natomiast orzechowy - Volpato (XVII/XVIII w.). Zob.: T. Bardwell, The Practice of Painting and Perspective Made Easy (Anglia 1756). Traktat ten został szeroko omówiony w pracy: M. Kirby Halley, K. Greon, Thomas Bardwell and his practice of painting: a comparative investigation between described and actual painting technique, „Studies in Conservation", 1975, no. 20, s. 44-108; Volpato manuscript, [w:] M. P. Merfield, Original treatises on the arts of painting, vol. 2, New York 1967, s. 728-730.

54 Wszelkie ugięcia nitek na krajkach pokrywają się z miejscami gwoździ przytwierdzających płótno do krosien. Z drugiej jednak strony, krawędzie krajek są bardzo dobrze zachowane i ostro zakończone, mogły więc zostać nieco przycięte pod- 
snach pomocniczych ${ }^{55}$. Płótno po napięciu na krosna zostało przeklejone klejem glutynowym ${ }^{56}$. Następnie została na nie nałożona biała zaprawa olejna na bazie bieli ołowianej z domieszka kredy. Z analizy przekrojów wynika, iż naniesiono ją w jednej warstwie. Zaprawa ma grubość od 42 do $126 \mu \mathrm{m}$. Na podstawie analizy przekrojów stwierdzono, że jej powierzchnia jest raczej gładka. Można przypuszczać, że była nakładana za pomocą noża, tak by wypełnić nierówności płóciennego splotu.

Kolejny etap po przygotowaniu zaprawy stanowiło wykonanie rysunku. Badania dowiodły, że został on sporządzony czarną farbą. Ma on charakter linearny, bez opracowania światłocieniowego. Cechy linii wskazuja na użycie suchego materiału. Zapewne posłużył do tego celu sztyft z węgla drzewnego ${ }^{57}$. Nie jest możliwe stwierdzenie, czy rysunek został wykonany odręcznie, bezpośrednio na podobraziu, czy też został przeniesiony na podłoże z wcześniej przygotowanego szkicu lub gotowego wzoru. Badany obraz jest szesnastokrotnie mniejszy od oryginału i wiernie powtarza

czas procesu konserwacji. Mogło to zatrzeć ślady po mocowaniu płótna na krosnach pomocniczych.

55 Zaprawa znajdująca się na krajkach może świadczyć również o tym, że obraz został namalowany na handlowym, już zagruntowanym płótnie, sprzedawanym z wałka na metry. B. J. Rouba, Budowa techniczna obrazón XIX-wiecznych malowanych na handlowych podobraziach płóciennych i problematyka ich konserwacji, Toruń 1988, s. 11-22.

56 Klej nakładano na rozpięte na krosnach płótno za pomocą pędzla. Następnie jeszcze mokry klej wyrównywano nożem lub już wyschnięty szlifowano pumeksem. De Mayerne pisze, że do przeklejania stosowano klej skórny ze skóry cielęcia lub koźlątka, Volpato wymienia klej skórny pergaminowy, Pernety zaś - klej rękawiczy (kozi) w formie zastygniętej, galaretowatej. Zob.: Volpato manuscript, s. 728-730; T. de Mayerne, Pictoria, sculptoria, et quae subalternarum atrium, 1620, [w:] E. Berger, op. cit., s. 103, 117, 259, 339, 249. Pernety, Dictionnaire portatif de peinture, sculpture et gravure, 1757, [w:] J. Hopliński, op. cit., s. 128. Również przygotowanie gotowych „fabrycznych płócien malarskich" przebiegało w zbliżony sposób. Płótno przeklejano i gruntowano już na właściwych krosnach lub - w przypadku płócien sprzedawanych „na metry” - na dużych krosnach pomocniczych. B. J. Rouba, Budowa technic₹nna, s. 19-20.

57 O sporządzeniu rysunku za pomocą wierzbowego węgla pisze de Mayerne, który uważa, że powinien on być wykonany łatwo ścierającym się materiałem, co umożliwia wygodne nanoszenie korekt. Gdy rysunek jest poprawny, zaleca wzmocnić go pędzlem, czarną farbą olejną z sykatywą (np. miedzianka). Zob. T. de Mayerne, op. cit., s. 279. 
jego ogólne formy i kierunki. Rysunek mógł zostać pomniejszony i przeniesiony na podobrazie za pomoca graticoli ${ }^{58}$. Na zdjęciu w podczerwieni nie ma jednak śladów jej stosowania w postaci podziału na kwadratowe pola. Ogólny zarys kompozycji mógł zostać przeniesiony z istniejącego już wzoru lub wcześniej wykonanego rysunku. Do tego celu wykorzystywano kalki bądź przepróchę ${ }^{59}$. Za użyciem kalki przemawiaja, widoczne na zdjęciu w IR, cienkie, przerywane, ostro zakończone linie. Mogły one powstać w wyniku odciskania szkicu. Opracowanie malarskie nie pokrywa się ściśle ze sporządzonym rysunkiem. W partiach twarzy postaci pierwszoplanowych są zauważalne nieznaczne zmiany i przesunięcia niektórych detali.

Obraz został namalowany w technice alla prima, z zastosowaniem farb olejnych. Nie stwierdzono obecności warstwy barwnej imprimatury. $\mathrm{Na}$ wykonanych przekrojach można wyróżnić od jednej do trzech warstw. Nie występują wyraźne granice między nimi. Ziarna pigmentów są mocno przemieszane na skutek ruchów pędzla przy nakładaniu kolejnych warstw na jeszcze niewyschnięte partie spodnie. Świadczy to o tym, że malarz namalował obraz szybko, a poszczególne warstwy były kładzione metoda „mokre w mokre” lub też w niedługich odstępach czasu, tak że warstwy spodnie nie wyschły dostatecznie. Artysta pracował równocześnie nad wszystkimi partiami obrazu, podnosząc światła i pogłębiając cienie. Dukt pędzla, wyraźnie widoczny w najwyższych światłach, dowodzi, że farba,

58 O stosowaniu tzw. graticoli pisze Volpato w manuskrypcie powstałym w latach 1670-1712. Graticola stanowiła prostokątną ramę z rozciagniętymi sznurkami, tworzącymi sieć o kwadratowych polach. Przykładano ją do kopiowanego obrazu, tak by dzieliła jego powierzchnię na kwadraty. Zagruntowane płótno (większe lub mniejsze od kopiowanej kompozycji) dzielono na kwadraty w takich samych proporcjach. Zob. Volpato manuscript, s. 736-737.

59 Volpato pisze m.in. o sposobie wykonania przezroczystego papieru przez natarcie go olejem. Taki papier wykorzystywano do przerysowywania wzoru. Następnie rysunek odbijano na podobraziu przez papier zaczerniony od spodu węglem lub czarną kreda. Kontury rysunku odciskano za pomocą igły z kości. Zob. ibidem, s. 736. Sposoby przenoszenia rysunku m.in. za pomoca przepróchy, kratkowania, przerysu wymienia Vincenzo Giustiniani. Zob. V. Giustiniani, List do Dirka Ameydena (ok. 1620), tłum. J. Białostocki, [w:] Teoretycy, historiografowie i artyści o sztuce 1600-1700, pod red. M. Poprzęckiej, A. Ziemby, Warszawa 1994, s. 28-33. 
którą nanosił, była gęsta, z małą ilością spoiwa, a używane pędzle miały sztywne włosie ${ }^{60}$. Partie półtonów i głębokich cieni były natomiast miękko modelowane farbami laserunkowymi lub półlaserunkowymi, z duża ilościa spoiwa. Posłużyły do tego zapewne innego rodzaju pędzle, z bardziej miękkiego włosia ${ }^{61}$. Ostatni etap pracy malarza stanowiło nałożenie laserunków, mające na celu przytłumienie zbyt jasnych, jaskrawych barw oraz przede wszystkim przyciemnienie cieni i scalenie poszczególnych partii kompozycji. Dzięki końcowemu ciemnobrązowemu laserunkowi uzyskano efekt wyłaniania się postaci z mroku i podziału kompozycji na dwa plany. Laserunki przyciemniające były kładzione na niedostatecznie wyschnięta farbę spodnia, co spowodowało liczne spękania pierwotne w wielu miejscach. Fakt ten dodatkowo potwierdza, że obraz był malowany szybko i nie zawsze zgodnie z zasadami technologicznymi. Skład ciemnej laserunkowej farby zastosowanej do wykończenia obrazu nie został zbadany. Prawdopodobnie jest to brąz pochodzenia bitumicznego ${ }^{62}$.

Sposób opracowywania karnacji postaci pierwszoplanowych różni się nieco od potraktowania karnacji postaci w tle. Wizerunki Madonny i Dzieciątka zostały ukazane bardziej szczegółowo, z większą precyzją w traktowaniu detali twarzy czy dłoni. Namalowano je praktycznie bez-

60 Aby otrzymać gęstą farbę do malowania partii jasnych świateł, dodawano do niej wypełniacze mineralne (mączkę marmurowa, kaolin, związki wapnia). Zob. Serenissima. Światto Wenecji. Katalog wystawy. Drieła mistrzón weneckich XIV-XVIII wieku ze zbiorów Muzeum Narodowego w Warszawie w swietle nowych badan technologicznych, historycznych i prac konserwatorskich, pod red. G. Bastek, G. Janczarskiego, A. Ziemby, Warszawa 1999, s. 229.

${ }^{61}$ Miękkie pędzle do laserunków wytwarzano m.in. z włosia borsuka i tchórza. Zob. http://www.essentialsvermeer.com (dostęp: 17.04.2008).

62 Wśród ciemnych, brązowych laserunkowych farb stosowanych powszechnie w XVII i XVIII w. można wymienić brunat van Dycka, brunat kasselski, asfalt. Asfalt, barwnik pochodzenia bitumicznego, był używany od połowy XVI w. Jest on barwnikiem bardzo ciemnym i jednocześnie laserunkowym. Praktycznie nie wysycha w oleju. Można go wykorzystywać jedynie do laserunków końcowych. Stosowany w partiach spodnich, powoduje spękania pierwotne w postaci szerokich rozejść. W XVII w. jako brązowy pigment stosowano również brunat kasselski (mielony węgiel brunatny lub glinka bitumiczna) - farbę laserunkową w oleju o bardzo ciemnej barwie. Brunat van Dycka jest odpowiednikiem brunatu kasselskiego lub mieszaniną czerni, czerwieni krapowej i węgla. Zob. B. Slánský, op. cit., s. 57. 
pośrednio na białej zaprawie. Podmalowanie malarskie, jeśli występuje, to tylko miejscowo. Malarz podmalował zapewne partie cieni w karnacji laserunkowo, za pomocą farby brązowej, aby ułatwić sobie opanowanie formy. Ton podstawowy użyty do namalowania karnacji postaci pierwszoplanowych stanowiła farba składająca się z mieszaniny bieli ołowianej, żółcieni żelazowej z domieszką czerwieni, czerni i zieleni. Światła były podnoszone przez zwiększanie udziału bieli w farbie. Najwyższe światła artysta wydobył dzięki zastosowaniu gęstej białej farby, kładzionej impastowo. W tych partiach jest widoczny dukt pędzla, którym pracował. Granice między najwyższymi światłami a półtonami i cieniami sa zatarte, poszczególne warstwy farby miękko wtapiają się w siebie. W ten sposób autor obrazu starał się uzyskać łagodne przejścia tonalne. Cienie w obrazie zostały przyciemnione brązowym laserunkiem o niezidentyfikowanym składzie. Ostatnim etapem opracowywania karnacji było podkreślenie rysunku detali twarzy Dzieciątka i Marii (oczu, nosa, uszu, ust) farbą czerwona, prawdopodobnie z czerwieni organicznej. Tej samej farby malarz użył do nadania chłodnego, różowego tonu niektórym partiom karnacji (policzkom, palcom, uszom, pośladkom). Zostały one opracowane wcześniej, zapewne farbą z bieli z dodatkiem cynobru lub minii. Włosy Dzieciątka i Madonny stosunkowo dokładnie opracowano na etapie rysunku. Podmalowano je ciepłą szarością i brązem. Następnie całość pokryto brązowym laserunkiem, przypuszczalnie takim samym jak cienie w karnacji. Włosy pozostałych postaci zostały opracowane w podobny sposób, jednak końcowy laserunek wykonano farbą w cieplejszym odcieniu. Również karnacje postaci drugoplanowych, dużo ciemniejsze i cieplejsze, zostały opracowane tak samo jak karnacje Madonny i Dzieciątka. Do ich namalowania zastosowano farbę, w skład której wchodziły przede wszystkim pigmenty żelazowe. Światła podnoszono, dodając bieli. Rysunek detali twarzy poprawiono czarną farbą, używając cienkiego pędzla. Ostatni etap pracy nad karnacjami postaci drugoplanowych stanowiło scalenie ich z tłem za pomocą ciemnego laserunku. Dało to efekt cofnięcia ich w głąb kompozycji. Spodnie warstwy nie były dostatecznie wyschnięte, stąd w partiach tych pojawia się gęsta arabeska spękań pierwotnych. Ciemne tło zostało opracowane ciemna farba, praktycznie w jednej warstwie. W związku z tym, że zaprawa jest koloru białego, farba została nałożona kryjąco, ale gładko. W jej skład wchodziły czerń roślin- 
na, błękit pruski, czerwień żelazowa i umbra. Na koniec nałożono ciemny laserunek scalający. Ciemnobłękitny płaszcz Madonny opracowano również alla prima, farbą na bazie błękitu pruskiego. Światła zostały nałożone kryjąco, farba jasną o zielonkawym odcieniu na bazie bieli ołowianej, błękitu pruskiego z domieszką żółcieni i czerwieni. Partie najgłębszych cieni wzmocniono ciemnym laserunkiem, składającym się prawdopodobnie z czerni z dodatkiem błękitu pruskiego (il. 8-9). Czerwone szaty Madonny i Świętego zostały opracowane w zbliżony sposób. Modelowano je farbą na bazie czerwieni i brązów żelazowych, światła podnosząc na mokro tą samą farbą z dodatkiem bieli ołowianej i żółcieni żelazowej. W partii czerwonej szaty Świętego kolor pogłębiono laserunkiem z czerwieni organicznej z domieszką czerwieni żelazowej. Czerwień żelazowa $\mathrm{w}$ warstwie laserunku może jednak w tym przypadku pochodzić z warstwy spodniej. Laserunek kładziono bowiem na niewyschnięte wcześniejsze opracowanie. Najgłębsze cienie zostały przyciemnione ciemnoczerwonym laserunkiem (skład nieznany). Najsilniej oświetloną część czerwonej szaty Madonny, tj. rękaw, opracowano w światłach farbą na bazie bieli ołowianej z dodatkiem czerwieni. Pigment czerwony stanowił zapewne cynober lub minia. Najwyższe światła podnoszono na mokro samą bielą. Malarz operował gęstą farbą. W miejscach tych, w odróżnieniu do partii zacienionych, jest wyraźnie widoczny dukt pędzla. Półtony i najgłębsze cienie zostały pokryte czerwonym laserunkiem prawdopodobnie z czerwieni organicznej. Obraz został napięty na fazowane krosna o połączeniach ruchomych, widlicowych z dwoma klinami. Ruchome krosna z fazami rozpowszechniły się dopiero w połowie XIX wieku ${ }^{63}$. Nie można jednak wykluczyć, że w procesie konserwacji krosna zostały wymienione, a gwoździe wbite dokładnie w te same miejsca, w których znajdowały się pierwotne gwoździe, tak by nie uszkodzić płótna.

${ }^{63}$ Do połowy XVIII w. powszechnie stosowano krosna w postaci ramy ze sztywno połączonych listew. W drugiej połowie XVIII i na początku XIX w. zaczęły rozpowszechniać się krosna o połączeniach ruchomych z klinami. Były one jednak na ogół niefazowane. Zob. A. Diakowska-Czarnota, op. cit., s. 32. 


\section{Próba datowania obrazu i określenia proweniencji warsztatowej}

Analiza materiałów użytych do wykonania badanego obrazu wykazała, że nie wszystkie były rozpowszechnione w XVII wieku. Wykrycie błękitu pruskiego wśród pigmentów wykorzystanych przez malarza sugeruje, iż dzieło musiało powstać w XVIII stuleciu, raczej w jego drugiej połowie. Błękit pruski to pigment sztuczny. Znana jest dokładna data jego otrzymania - po raz pierwszy został uzyskany w 1704 roku w Berlinie przez Heinricha Diesbacha, jednak, według literatury, na szerszą skalę zaczęto go stosować w malarstwie dopiero od połowy XVIII wieku ${ }^{64}$. Począwszy od końca tego stulecia, liczba nowych, otrzymywanych sztucznie pigmentów, używanych w malarstwie, zaczęła gwałtownie wzrastaćc5.

Paletę zastosowana do namalowania badanej kompozycji tworza pigmenty wykorzystywane w malarstwie od wieków. Czerwienie, żółcienie i brązy żelazowe, podobnie jak czerń roślinna czy czerwień organiczna, były znane od czasów starożytnych i nadal chętnie stosowane w XVII, XVIII i XIX wieku. Biel ołowiana stanowiła najpopularniejszy pigment biały do połowy XIX wieku, kiedy to zaczęła ją wypierać biel cynkowa ${ }^{66}$. Poza błękitem pruskim nie zidentyfikowano w obrazie żadnego z innych nowo wprowadzanych na paletę sztucznych pigmentów $^{67}$. Natomiast spoiwo olejne, którego występowanie potwierdzono w opracowaniu malarskim, było niezwykle popularne w malarstwie europejskim przynajmniej od czasów Jana van Eycka (pierwsza połowa XV w.). Od XVII wieku olej lniany stanowił podstawę farb stosowanych w warsztatach malarskich w całej Europie. W XVIII i w pierwszej połowie XIX wieku jako spoiwa do farb chętnie używano, obok oleju lniane-

64 B. Slánský, op. cit., s. 49.

65 R. J. Gettens, G. L. Staut, Painting materials: short encyclopedia, New York 1966, s. $141-143$

66 B. Slánský, op. cit., s. 24-25.

67 Od końca XIX w. następuje znaczny wzrost liczby pigmentów w palecie malarskiej na skutek wielu odkryć nowych pigmentów. Zob. W. Ślesiński, Na ç̧ym i caymm malowano, s. 123. 
go, także oleju makowego, ze względu na jego bezbarwność, oraz oleju orzechowego. Dodawanie oleju makowego lub orzechowego zalecano zwłaszcza do bieli ołowianej ${ }^{68}$.

Płótno, które posłużyło jako podobrazie, zostało utkane na krosnach ręcznych ${ }^{69}$, wykorzystywanych powszechnie do połowy XIX wieku ${ }^{70}$. Obecność zaprawy na krajkach sugeruje, że do namalowania obrazu użyto prawdopodobnie podobrazia fabrycznego (handlowego). Według literatury gotowe podobrazia pojawiły się w handlu w połowie XVIII wieku. Dostępne były dwa rodzaje zagruntowanych płócien - zagruntowane od razu na różnego formatu krosnach właściwych oraz sprzedawane $z$ wałka na metry $^{71}$. W przypadku analizowanego obrazu płótno musiało zostać zakupione bez krosien ${ }^{72}$. Ma ono drobny gren $\mathrm{i}$ jest gęste, a jego faktura, mimo cienkiej zaprawy i warstwy malarskiej, słabo ujawnia się na licu. Powrót do tego typu płócien - gęstych, bardziej gładkich i równomiernie tkanych, nastapił w XVIII wieku, a na początku XIX wieku płótna o drobnym gre-

68 Ibidem, s. 121. Oleje makowy i orzechowy wymienia m.in. praca z 1764 r. N. N., The Handmaid to the Arts, cytowana przez Bergera. E. Berger, op. cit., s. 423. Olej makowy do pigmentów białych zaleca m.in. Bardwell (połowa XVIII w.), natomiast orzechowy - Volpato (XVII/XVIII w.). Traktat Bardwella, The Practice of Painting and Perspective Made Easy (Anglia 1756), został omówiony w pracy: M. Kirby Halley, K. Greon, op. cit., s. 44-108. Zob. też Volpato manuscript, s. 728-730.

69 Mechaniczne krosno tkackie wynaleziono już w 1787 r., a jego rozpowszechnianie następowało stopniowo w latach 1822-1870. Zob. B. J. Rouba, Ptótna jako podobrazia, s. 224. Zob. też. C. L. Eastlake, Materials for a history of oil painting, New York 1967; R. B. Gettens, G. L. Stout, op. cit.; M. P. Merrifield, Original treatises dating the 12th to 18th centuries on the art of painting, New York 1967.

70 B. J. Rouba, Ptótna jako podobrazia, s. 223.

71 Z połowy XVIII w. pochodzą najwcześniejsze wzmianki na temat tego typu płócien dostępnych w handlu. Od połowy XIX w. stały się one powszechne w użyciu. B. J. Rouba, Budowa technična, s. 11-22.

${ }^{72}$ W drugiej połowie XVIII i w pierwszej połowie XIX w. częściej spotykane w handlu były zagruntowane płótna umieszczone już na krosnach, z kolei te sprzedawane „na metry” były bardziej popularne w drugiej połowie XIX w. Zob. ibidem, s. 18. Jednak wzmiankę o dostępnych w sprzedaży tych dwóch typach gotowych podobrazi spotykamy w podręczniku autorstwa Bouviera (Manuel des jeunes artistes et amateurs, Paris 1827) z pierwszej połowy XIX w., którego fragmenty przytacza J. Szpor. Zob. J. Szpor, op. cit., s. 59. 
nie dominowały ${ }^{73}$. Zaprawa $\mathrm{w}$ kolorze białym, niestonowana chociażby barwiona imprimatura, nie jest typowa dla wieków XVII i XVIII. Ciemne, barwne grunty wprowadzone w drugiej połowie XVI wieku w północnych Włoszech ${ }^{74}$ rozpowszechniły się w następnym stuleciu w całej Euro$\mathrm{pie}^{75}$. Ciemne grunty odrzucono dopiero przy końcu XVIII i na początku XIX wieku, kiedy to pojawily się jasne zaprawy olejne ${ }^{76}$.

Biel ołowianą chętnie stosowano jako wypełniacz zapraw, zarówno w XVII, jak i XVIII wieku, m.in. ze względu na dobre właściwości sykatywujące, $z$ tym że na ogół występowała ona w mieszaninie z innymi pigmentami. Do gruntów często wykorzystywano ją w połączeniu z kredą ${ }^{77}$. Taka mieszanina jest określana $\mathrm{w}$ traktatach i podręcznikach malarskich jako cerus $^{78}$. Mieszanina bieli ołowianej z kredą w stosunku 1:1 nazywana jest bielą hiszpańską ${ }^{79}$. W przypadku obrazu z Muzeum Narodowego w Poznaniu kreda zawarta w zaprawie stanowi jedynie domieszkę. Białe zaprawy z wypełniaczem z bieli ołowianej z kreda pojawiaja się sporadycznie w XVIII wieku. Zidentyfikowano je w obrazach portrecisty angielskiego - Thomasa Bardwella (1704-1767). Przepisy na biały grunt

73 B. J. Rouba, Ptótna jako podobraz̨ia, s. 223; J. Szpor, op. cit., s. 59; B. Slánský, op. cit., s. 182-183.

74 Za prekursorów stosowania ciemnych barwionych gruntów uważa się w literaturze mistrzów weneckich Tycjana i Tintoretta. Zob. Serenissima, s. 229.

75 Traktat de Mayerne'a podaje liczne przepisy na zaprawy olejne na płótnie, jedno- lub dwuwarstwowe. Sa to jednak zawsze zaprawy barwne. Zob. T. de Mayerne, op. cit., s. (2), (14), (186), (194b), (190a), (214), (210). Grunty jednowarstwowe często występują w tym czasie w różnych odcieniach szarości (biel ołowiana z dodatkiem czerni, umbry, ochry, ugru). W przypadku podwójnych gruntów pierwsza warstwa była nakładana z tanich materiałów, przeważnie z czerwonych, brązowych lub żółtych pigmentów ziemnych. Druga warstwa miała często różne odcienie szarości. Główny składnik stanowiła biel ołowiowa z niewielkim dodatkiem kolorowych pigmentów i czerni węglowej. Zob. Still lifes: Techniques and style the examination of paintings from the Rijksmuseum, ed. A. Wallert, Amsterdam 1999, s. 11-12.

76 B. Slánský, op. cit., s. 38.

77 J. Czernichowska, op. cit., s. 198. Autorka podaje informację za: A. R. Duval, op. cit., s. 239-258.

78 Tak określa ją m.in. Watin w swoim traktacie (XVIII w.). J. F. Watin, op. cit. Zob. J. Szpor, op. cit., s. 56.

79 J. Hopliński, op. cit., s. 136. 
znajdują się także w traktacie Salmona. Sa to jednak zaprawy mieszane, kilkuwarstwowe: pierwsze warstwy sa ze spoiwem klejowym, a ostatnia ze spoiwem olejnym ${ }^{80}$. Od początku XIX wieku coraz większą popularność zaczynaja zdobywać białe zaprawy olejne. W handlu pojawiaja się białe fabryczne grunty ze spoiwem olejnym ${ }^{81}$. W ich skład wchodzi, jak w przypadku badanego obrazu, biel ołowiana $\mathrm{z}$ dodatkiem kredy ${ }^{82}$.

Technika malarska analizowanego obrazu pozostaje w pewnej sprzeczności ze stylowo-estetycznym charakterem kompozycji. Przedstawienie wizualnie jest wzorowane na XVII-wiecznym malarstwie tenebrystycznym. Nawiązanie to okazuje się jednak powierzchowne, uzyskane za pomoca uproszczonych środków. W malarstwie światłocieniowym ważną rolę odgrywał bowiem ciemny kolor gruntu. Ciemny podkład wpływał na efekt malarski, dyktował też sposób malowania. Uwidaczniał się w półtonach i cieniach, które były przyciemniane laserunkami. Światła podnoszono przez nakładanie silnie rozbielonej farby. Przez stopniowanie bieli otrzymywano dużą skalę optycznych szarości, dzięki czemu technika ta dawała najlepsze efekty światłocieniowe ${ }^{83}$. W zestawieniu z oryginalną kompozycją modelunek form w badanym obrazie wydaje się płaski

80 Salmon zaleca w swoim traktacie (W. Salmon, Polygraphice: or the Arts of Drawing, Engraving, Etching, Limning, Varnishing, japaning, Gilding, \&c., 1672) przeklejać płótno klejem z dodatkiem miodu, następnie nakładać warstwy białej zaprawy klejowej z wypełniaczem z bieli ołowianej i kredy, a na koniec warstwę z bieli ołowianej ze spoiwem olejnym. Zob. M. Kirby Halley, K. Greon, op. cit., s. 54-59.

81 Wiele informacji na temat zapraw stosowanych w XVIII i XIX w. zawiera pozycja: J. Szpor, op. cit., s. 47-58. Autorka przytacza fragmenty dotyczące zapraw z podręczników malarskich z XVIII i początku XIX w., takich jak: J. F. Watin, L'art du Paintre, Doreur, Vernisseur (1751); P. L. Bouvier, Manuel des jeunes artistes et amateurs (1827).

82 O płótnach fabrycznie gruntowanych na biało (la cerusa) wspomina m.in. Bouvier. Zob. J. Szpor, op. cit., s. 59. Zaprawy o takim samym składzie jak w analizowanym obrazie zostały zidentyfikowane w większości XIX-wiecznych obrazów zbadanych i opisanych w pozycji: B. J. Rouba, Budowa techniczna, oraz w czterech spośród dwudziestu trzech zbadanych i opisanych przez W. Ślesińskiego (przy czym prawie wszystkie to zaprawy białe, olejne); zob. idem, Na csym i czym malowano, s. 123.

83 E. Basiul, Droga powstawania określonych efektów kolorystycznych na powierzchniach obrazów sztalugowych, „Acta Universitatis Nicolai Copernici. Zabytkoznawstwo i Konserwatorstwo", 2002, t. 32, s. 2-29. 
(il. 10-13) ${ }^{84}$. Może to wynikać z mniejszych umiejętności malarskich kopisty, ale najprawdopodobniej z braku wiedzy na temat malarstwa wielowarstwowego i odpowiedniego doświadczenia w tym zakresie.

\section{Podsumowanie}

Obraz Madonna z. Dzieciatkiem i Świetymi jest znacznie pomniejszoną wersją drezdeńskiego pierwowzoru. Badane dzieło wykazuje cechy kopii wykonanej w okresach późniejszych, o czym świadczy naśladowanie wyłącznie powierzchownych cech obrazu, takich jak forma czy kolor. Takie reprodukcje malowano w odmienny sposób, zgodny z czasem, w jakim powstawały. Należy wspomnieć, że w okresie, który może być w tym przypadku brany pod uwagę, tj. od XVII do XIX wieku, kopiowanie stanowiło proceder bardzo popularny. Jednocześnie było ważnym elementem kształcenia akademickiego. Trzeba dodać, że Akademia Sztuki w Dreźnie istniała od 1764 roku, a prawie równocześnie w Monachium zaczęła działać szkoła artystyczna (od 1770 r.), zwana już wtedy akademia ${ }^{85}$. Jej studenci kopiowali nie tylko rysunki wielkich mistrzów, ale także obrazy olejne ${ }^{86}$. Poza kopią edukacyjną badany obraz mógłby rów-

84 Kolor zaprawy, na której namalowano pierwowzór, nie został zbadany. Zastosowania ciemnej zaprawy dowodzą uzyskane efekty malarskie. Przemawia za tym również okres, w którym tworzył Procaccini (przełom XVI i XVII w., północne Włochy), oraz kontakt $z$ malarstwem weneckim, w tym z dziełami Tycjana, i czerpanie $z$ niego inspiracji.

85 Pierwsze akademie zaczęto zakładać we Włoszech już w XVI w. Ostateczny kształt akademii osiągnięto we Francji, powołując w 1648 r. Królewską Akademię Malarstwa i Rzeźby. Dała ona początek i wzór podobnym instytucjom w całej Europie. Zob. http://www.hfbk-dresden.de/HfBK-resden/Hochschule/Einrichtungen/Kustodie.php (dostęp: 2.05.2008). Dopiero w 1808 r. król bawarski Maksymilian I Józef Wittelsbach powołał Królewską Akademię Sztuk Pięknych (Zeichnungs Schule Respective Maler und Bildhauer Akademie). Zob. http://www.naukowy.pl/ /encyklopedia/Akademie_der_Bildenden_Künste_München (dostęp: 5.05.2008). Od początku XIX w. kształcenie odbywało się już wyłącznie w akademiach. Zob. Stownik terminologiczny sztuk pieknych.

86 W. Ślesiński przytacza program nauczania na Wydziale Sztuk Pięknych Uniwersytetu Warszawskiego, sformułowany przez A. Brodowskiego (Uwagi do 
nież stanowić kopię warsztatowa. Wielu artystów malowało powtórzenia własnych prac (tzw. kopie autorskie), mieli oni też swoje pracownie, w których uczniowie wykonywali repliki wcześniejszych kompozycji lub ich różne warianty ${ }^{87}$. Nie wiemy, czy Procaccini prowadził tego typu pracownię. Poza tym dużo niższa jakość artystyczna obrazu w porównaniu do dzieł Procacciniego przemawia za tym, że twórca analizowanej reprodukcji wywodził się spoza kręgu artysty. Kopie warsztatowe sa na ogół zgodne z techniką i technologia oryginału, uczniowie postępowali bowiem według szczegółowych wytycznych mistrza ${ }^{88}$. W tym przypadku jest inaczej, ponieważ kopia pod względem budowy znacznie odbiega od pierwowzoru.

Kopiści do końca XIX wieku nie zwracali uwagi na technikę wykonania odtwarzanej kompozycji. Nie posiadali żadnej wiedzy na temat warsztatu malarskiego dawnych mistrzów. Posługiwali się więc nagminnie materiałami dostępnymi i aktualnie wykorzystywanymi $\mathrm{w}$ innych działaniach artystycznych, nie tylko podczas kopiowania. Pewne zrozumienie techniki malarskiej stosowanej we wcześniejszych epokach nastąpiło dopiero pod koniec XIX wieku w środowisku monachijskim, wraz z rozwojem aktywności naukowej Ernesta Bergera, Maxa Pettenkofera $\mathrm{i}$ innych ${ }^{89}$.

urzadzania Szkoly malarstwa, 1820). Brodowski pisze, że uczniowie powinni kopiować obrazy w celu nauczenia się kolorytu. Z tego względu: „Szkoła Malarska powinna mieć kilka wzorowych obrazów sławnych kolorystów [...] nie oryginałów, bo te sa nazbyt kosztowne, sczerniałe [...] ale kilka kopii [...], które uczeń wiernie naśladując, nauczy się czystego i świetnego kolorytu”. Zob. W. Ślesiński, O sytuacji $w$ zakresie technologii i technik malarskich $w$ dobie romantyzmu, „Ochrona Zabytków”, 1966, nr 3, s. 13-21.

87 J. Flik, Kopia, replika, rekonstruk.ja w malarstwie sztalugowym, [w:] Problemy technologiczno-konserwatorskie malarstwa i rzę́by. Materiaty z sesji naukowej poświęconej pamięci Leonarda Torwirta, Toruń 9-10 listopada 1992, Toruń 1992.

88 B. Slánský, op. cit., s. 50.

89 I. Mohrmann, Moritz, Röbbeckes Gemäldekopien für Prinz Georg von Preußen, [w:] Die Kunst der Gemäldekopie, Beiträge der Tagung an der Hochschule für Bildende Kunste Dresden: Kunsttechnologie - Gemäldekopie - Reproduktion (29.11-2.12.2001), Verband der Restauratoren e.v., Bonn 2006. Pierwsze wyniki badań tych naukowców zostały zaprezentowane w 1893 r. na spotkaniu zorganizowanym przez Niemieckie Towa- 
Kopie były zazwyczaj malowane $\mathrm{w}$ technice alla prima $\mathrm{w}$ taki sposób, aby oddać od razu wartości barwne zauważalne w oryginale, także te, które wynikały z upływu czasu (pożółkły werniks, zabrudzenia, spękania). Zastosowane materiały nie zawsze okazywały się odpowiednie. Artyści używali często niesprawdzonych produktów handlowych, powodujących niezamierzone efekty pierwotnych zniszczeń w warstwach malarskich (spękania). Obraz z Muzeum Narodowego w Poznaniu doskonale wpisuje się w tę praktykę.

Przeprowadzone badania technologii i techniki malowania obrazu Madonna z Drieciatkiem $i$ Świetymi pozwoliły na zweryfikowanie informacji dotyczących jego datowania. Dzięki wykryciu w warstwach malarskich błękitu pruskiego, którego data otrzymania jest dokładnie znana, można z cała pewnością stwierdzić, że analizowane dzieło powstało po roku 1704. Sugerując się literatura, wskazująca na rozpowszechnienie się błękitu pruskiego dopiero w drugiej połowie XVIII wieku, jak również biorąc pod uwagę zastosowane podobrazie, a zwłaszcza rodzaj użytej zaprawy i sposób malowania, można przyjąć, że obraz stworzono najwcześniej w końcu XVIII wieku. Trudno jednak precyzyjnie określić miejsce jego powstania. Namalowanie go u schyłku XVIII stulecia, kiedy to pierwowzór znajdował się w Dreźnie, w którym działała już szkoła artystyczna, jest bardzo prawdopodobne. Przyjmując powyższą interpretację, można hipotetycznie stwierdzić, że obraz Madonna ₹ Drieciatkiem i Świetymi z Muzeum Narodowego w Poznaniu stanowi typowa kopię edukacyjna wykonana sprawnie, ale bez wiedzy o dawnych technikach malarskich. Nie należy jednak całkowicie wykluczać, że dzieło powstało w drezdeńskiej galerii na zamówienie indywidualnego zleceniodawcy, np. kolekcjonera.

rzystwo ds. Racjonalnego Postępowania Malarskiego. Podczas swojego wystapienia Ernest Berger ukazał historię rozwoju malarstwa na podstawie serii obrazów. 
Tab. 1. Materiały zidentyfikowane w obrazie Madonna z Drieciatkiem i Świętymi z Muzeum Narodowego w Poznaniu

\begin{tabular}{|c|c|c|}
\hline $\begin{array}{c}\text { Warstwa } \\
\text { technologiczna }\end{array}$ & \multicolumn{2}{|c|}{ Zidentyfikowane materiały } \\
\hline Podobrazie & \multicolumn{2}{|c|}{ płótno Iniane } \\
\hline Przeklejenie & \multicolumn{2}{|c|}{ klej glutynowy } \\
\hline & pigmenty & spoiwa \\
\hline Zaprawa & $\begin{array}{c}\text { biel ołowiana }-2 \mathrm{PbCO}_{3} \times \mathrm{Pb}(\mathrm{OH})_{2} \text {, } \\
\text { domieszka kredy }-\mathrm{CaCO}_{3}\end{array}$ & olej \\
\hline Warstwa malarska & $\begin{array}{c}\text { biele: biel ołowiana }-2 \mathrm{PbCO}_{3} \times \mathrm{Pb}(\mathrm{OH})_{2} \\
\text { żółcienie: żółcienie żelazowe }-\mathrm{Fe}(\mathrm{OH})_{3} \\
\text { czerwienie: czerwień żelazowa }-\mathrm{Fe}_{2} \mathrm{O}_{3} \\
\text { czerwień organiczna } \\
\text { cynober - } \mathrm{HgS} \text { lub minia - } \mathrm{Pb}_{3} \mathrm{O}_{4} \\
\text { czernie: czerń roślinna } \\
\text { brązy: umbra lub sjena palona } \\
\text { błękity: błękit pruski - } \mathrm{Fe}_{4}\left[\mathrm{Fe}(\mathrm{CN})_{6}\right]_{3} \\
\text { zielenie: zieleń miedziowa (?) }\end{array}$ & olej \\
\hline
\end{tabular}

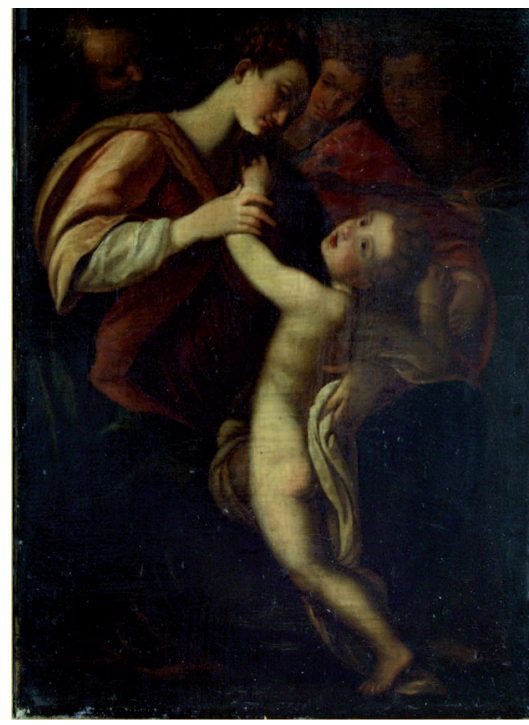

Il. 1. Madonna z Drieciatkiem i Świetymi olej na płótnie, $41 \times 27,7 \mathrm{~cm}$, Muzeum Narodowe w Poznaniu (fot. A. Cupa)

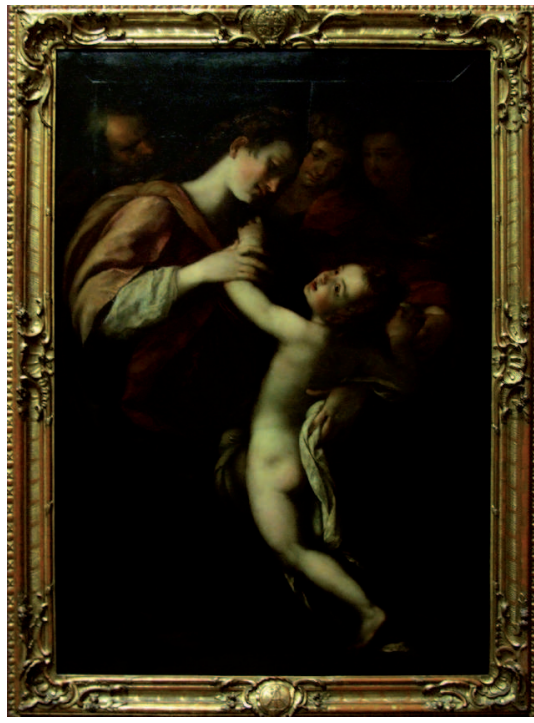

Il. 2. G. C. Procaccini, Święta Rodzina, olej na drewnie, $162 \times 107,5 \mathrm{~cm}$, Muzeum Narodowe w Dreźnie (fot. E. Mitura) 


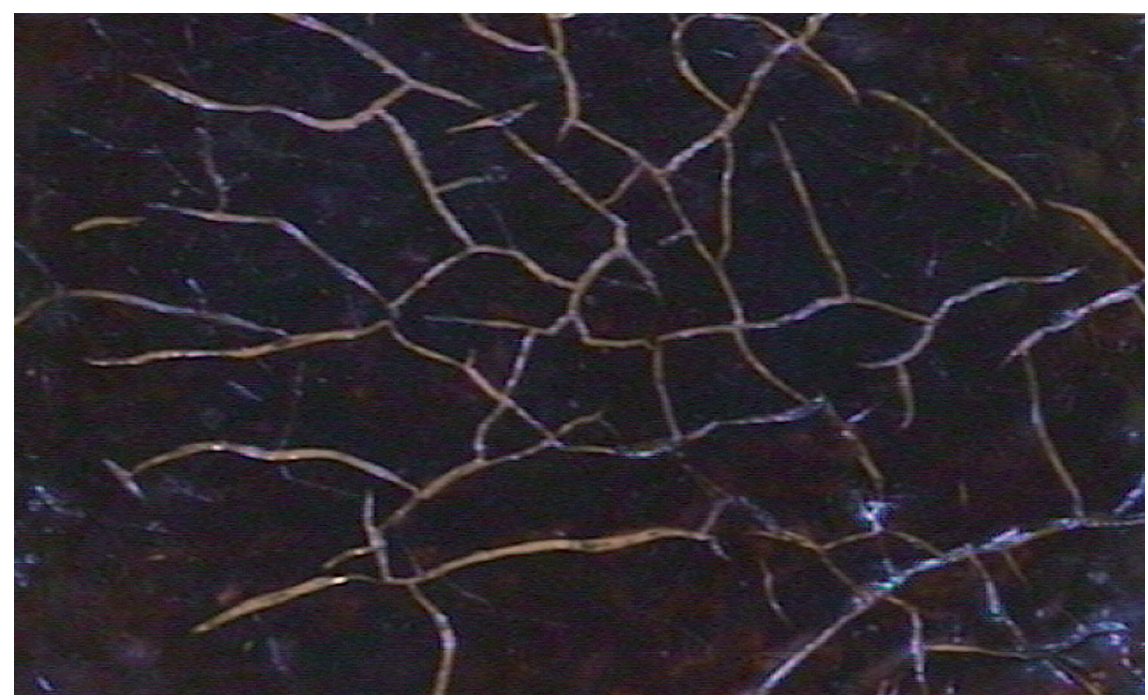

Il. 3. Madonna z Drieciatkiem i Świettymi, fragment, fotografia makroskopowa, pow. 100x (fot. A. Cupa)

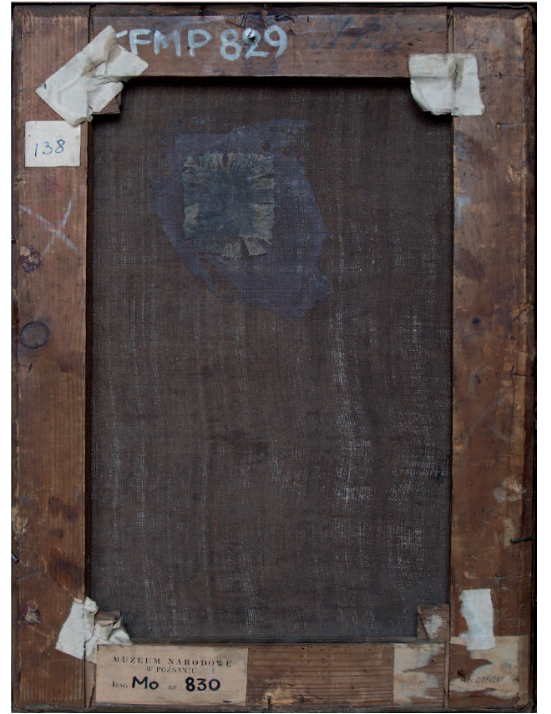

Il. 4. Madonna z. Drieciatkiem i Świetymi, odwrocie obrazu (fot. A. Cupa)

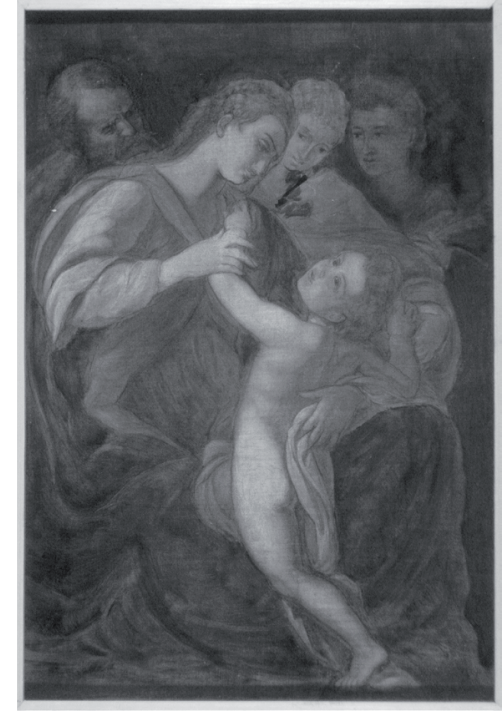

Il. 5. Madonna z. Drieciatkiem i Świetymi, zdjęcie lica obrazu w zakresie bliskiej podczerwieni - reflektografia IR (fot. A. Cupa) 


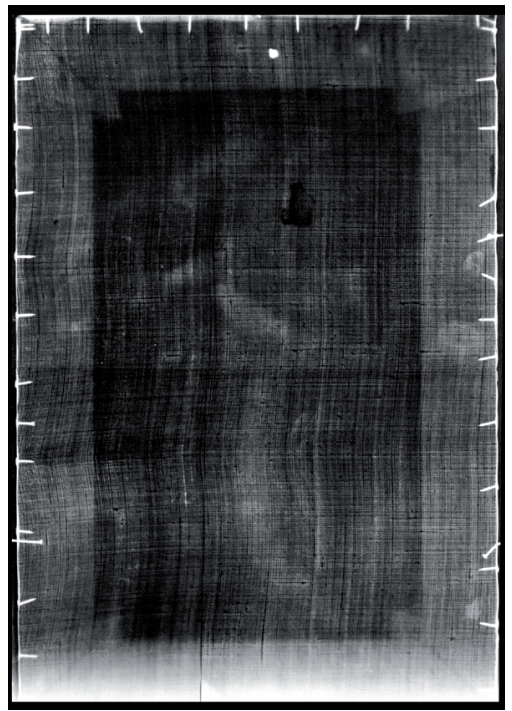

Il. 6. Madonna z Drieciatliem i Świety$m i$, zdjęcie w kolorowej podczerwieni (fot. A. Cupa)



Il. 7. Madonna z. Drieciatkiem i Świetymi, zdjęcie w promieniach Roentgena (fot. Pracownia rentgenowska APL UMK)

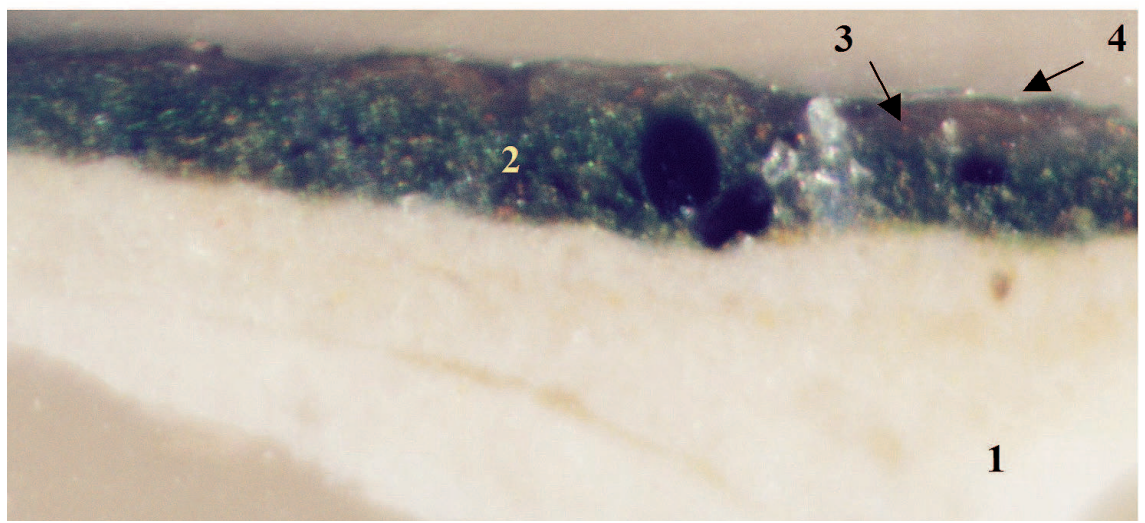

Il. 8. Fotografia mikroskopowa w świetle widzialnym próbki nr 2 (pow. 200×). Widoczny układ warstw malarskich (fot. Z. Rozłucka):

1 - warstwa biała - zaprawa;

2 - warstwa błękitnozielona - widoczne cząstki ciemnobłękitne, białe, żółte, pojedyncze czerwone; cząstki są drobne, mocno przemieszane; widoczne większe skupiska zbitych ciemnobłękitnych cząstek;

3 - warstwa werniksu;

4 - warstwa zabrudzeń 


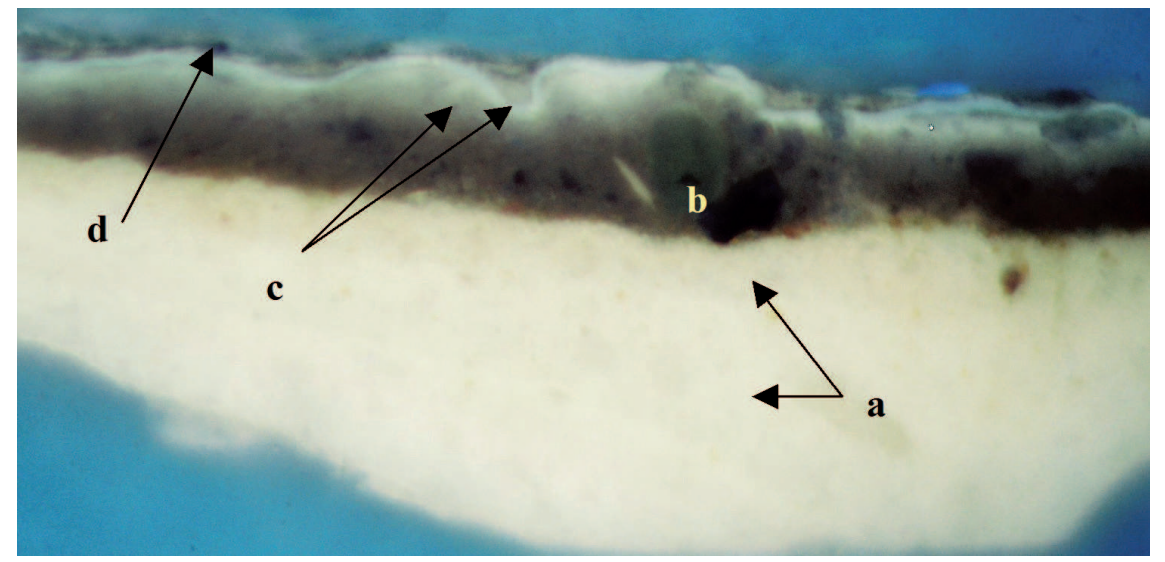

Il. 9. Fotografia mikroskopowa w świetle UV próbki nr 2 (pow. 200×) (fot. Z. Rozłucka): a - podział zaprawy na dwie warstwy, wynikający z wniknięcia oleju z warstwy malarskiej do jej górnej partii;

$\mathrm{b}$ - wygaszenie promieniowania UV w warstwie ciemnobłękitnej przez pigment ciemnobłękitny, wskazujące na błękit miedziowy lub żelazowy;

c - uwidocznione warstwy werniksu;

d - wygaszanie promieniowania UV przez warstwę zabrudzeń

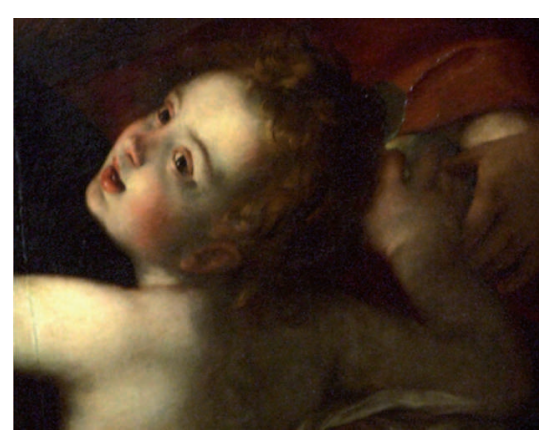

Il. 10. Madonna z Drieciatkiem i Świetymi, fragment - karnacja Dzieciątka (fot. A. Lubochońska)

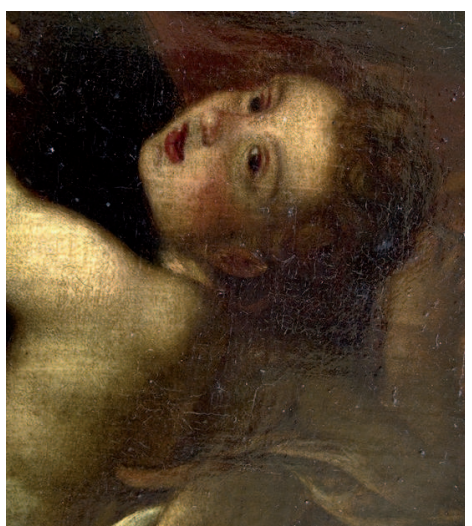

Il. 11. G. C. Procaccini, Święta Rodżina, fragment - karnacja Dzieciątka (fot. E. Mitura) 


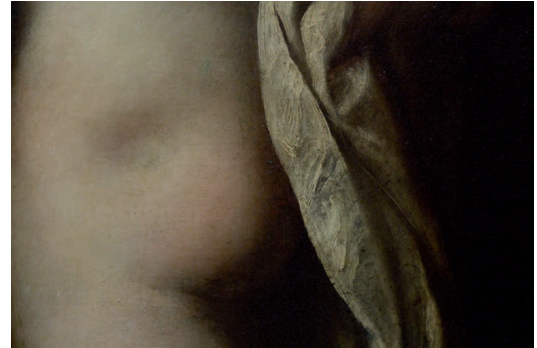

Il. 12. Madonna z Drieciatkiem i Świetymi, fragment - karnacja Dzieciątka (fot. A. Lubochońska)

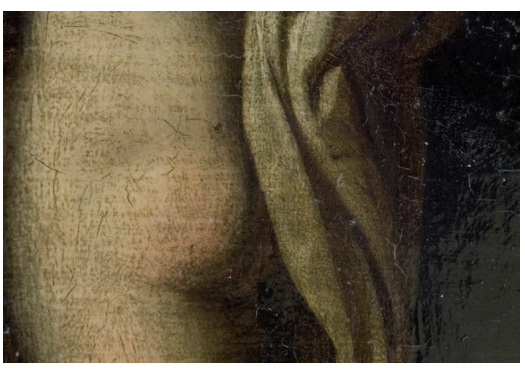

Il. 13. G. C. Procaccini, Świetta Rodzina, fragment - karnacja Dzieciątka. Widoczne spękania pierwotne, występujące $\mathrm{w}$ partiach karnacji w wielu miejscach, zgodne ze śladem pędzla (fot. E. Mitura)

\section{Summary}

\section{Painting Virgin with the Child and Saints prescribed to the follower of Giulio Cesare Procaccini - an atempt to date and attribute the work on the basis of the examination of the painting technique}

The study consists on a characteristics of a painting Virgin with the Child and Saints from the National Museum in Poznań. It includes a draft history of the painting and an attempted comparison with the prototype attributed to Giulio Cesare Procaccini, in terms of painters' workshop. To achieve that technical and technological research was performed by non-destructive analytical methods and by examination of samples. The results were presented against the background of the literature on the development of artists' materials and techniques form $17^{\text {th }}$ century to the first half of $19^{\text {th }}$ century. That allowed for verification of the former dating and assumed place of execution. The results confirmed that the investigated painting is a much smaller copy of a painting from the collection of the Museum in Dresden. The suggested time and place of painting the copy is Dresden artistic environment of the late $18^{\text {th }}$ century. 